\title{
Treatment of reflux oesophagitis with ranitidine
}

\author{
I C E WESDORP, W DEKKER, AND E C KLINKENBERG-KNOL \\ From the Department of Gastroenterology, Andreas Hospital, Amsterdam, Elisabeth Gasthuis, Haarlem, and \\ the Academic Free University, Amsterdam. The Netherlands
}

SUMMARY The efficacy of ranitidine was evaluated using a two-staged trial in patients with endoscopically moderate or severe reflux oesophagitis. The results of a six week double blind placebo controlled trial (stage $\mathrm{I}$ ) in 36 patients shows that ranitidine $(150 \mathrm{mg} \mathrm{bd}$ ) is superior to placebo in the acute treatment with significant symptomatic improvement concerning heartburn and regurgitation, and in healing or improvement of endoscopic lesions. Prolonged treatment with ranitidine for another six weeks (stage II) proved to be effective in more resistant cases. No clinical side effects or significant biochemical changes were noted during this trial.

Histamine $\mathrm{H}_{2}$-receptor antagonists have potential use in the management of gastrooesophageal reflux disease. because they inhibit basal, nocturnal, and stimulated. gastric acid secretion and pepsin secretion. ${ }^{1-4}$ Results of several trials with cimetidine show that treatment with this drug in the case of reflux oesophagitis usually results in a rapid symptomatic improvement, reduction in the amount of concomitant antacid consumption, and improvement of the reflux damaged mucosa as can be seen from endoscopic and histologic assessments. ${ }^{5-8}$ The new $\mathrm{H}_{2}$-receptor antagonist ranitidine appears to be more potent ${ }^{+}$and probably longer acting. ${ }^{9}$ Furthermore, some workers report a positive influence on the lower oesophageal sphincter pressure ${ }^{10}$ although this has not been confirmed. "It therefore seemed appropriate to evaluate the efficacy of ranitidine in the acute treatment of reflux oesophagitis.

\section{Methods}

PATIENTS

Thirty eight adult outpatients were selected for this trial. The diagnosis was based upon a careful medical history, endoscopy, and biopsy. Informed consent was obtained from all patients.

\section{MEDICAL HISTORY}

All patients were asked to record the severity of heartburn, regurgitation, and retrosternal pain, previous treatment, and duration of the disease.

Address for correspondence: Dr I C E Wesdorp. Dept of Gastroenterology. Andreas Hospital. Th de Bockstr 8. 1058 NR. Amsterdam. The Netherlands Received for publication 29 December 1982
Each patient was provided with diary cards for a daily record of symptoms, scoring the number of episodes of reflux symptoms, the degree of severity (none, mild, moderate, or severe), and the number of antacids (Rennies) taken during the test period to relieve symptoms not controlled by the test medication.

\section{ENDOSCOPY AND BIOPSY}

Endoscopy was performed with standard forwardviewing instruments. Oesophagitis was defined as mild (erythema, friability; grade I), moderate (erosions; grade II), or severe (ulceration; grade III) using the criteria previously described ${ }^{6}$ Endoscopy was performed by experienced endoscopists without knowledge of patient symptomatology or treatment. The endoscopic findings at the end of the study were scored as unchanged (same degree), worse, or improved (when there was a change of at least one degree) or healed when compared to the pretrial findings. The degree of oesophagitis in the five or more pre- and post-trial endoscopic biopsies were defined as mild (grade I), moderate (grade II), and severe (grade III) using the criteria previously described. ${ }^{6}$ The pre- and post-trial biopsies were compared for each patient, and interpreted by experienced pathologists as unchanged (same degree), improved or worse (change of at least one degree). Only patients with endoscopically moderate or severe oesophagitis were admitted. Patients with concomitant ulcer, pregnant and lactating women, patients with previous oesophageal or stomach surgery, patients with strictures, and patients with serious diseases such as heart, liver, and kidney failure were excluded. 
Table 1 Characteristics of 36 patients (stage I)

\begin{tabular}{|c|c|c|c|c|c|c|c|c|c|c|c|c|}
\hline \multirow[b]{2}{*}{$\begin{array}{l}\text { Treatment } \\
\text { group }\end{array}$} & \multicolumn{2}{|c|}{ Age (yr) } & \multicolumn{2}{|c|}{ Sex } & \multirow{2}{*}{$\begin{array}{l}\text { Disease } \\
\text { duration } \\
\text { (mean) }\end{array}$} & \multicolumn{3}{|c|}{ Symptoms } & \multicolumn{2}{|c|}{ Endoscopy } & \multicolumn{2}{|c|}{ Histology } \\
\hline & Mean & Range & $M$ & $F$ & & Mild & $\begin{array}{l}\text { Mod- } \\
\text { erate }\end{array}$ & Severe & $\begin{array}{l}\text { Mod- } \\
\text { erate }\end{array}$ & Severe & $\begin{array}{l}\text { Mod- } \\
\text { erate }\end{array}$ & Severe \\
\hline Ranitidine & $53 \cdot 8$ & $31-75$ & 14 & 5 & $54.2 \mathrm{~m}$ & 2 & 10 & 7 & 14 & 5 & 9 & 10 \\
\hline Placebo & 6()$\cdot 2$ & $39-76$ & 11 & 6 & $67.1 \mathrm{~m}$ & 2 & 11 & 4 & 12 & 5 & 7 & 10 \\
\hline
\end{tabular}

In the first part of the trial (stage I) the patients were randomly allocated to either ranitidine $(150 \mathrm{mg}$ bd) or placebo treatment of six week duration. Each patient was also given a known number of antacid tablets (Rennies) to be taken solely for relief of symptoms when not controlled by the test medication. All patients were evaluated after six weeks for physical examination, for laboratory analysis (haemoglobin, blood erythrocyte sedimentation rate, peripheral blood count, plasma urea, serum creatinine, bilirubin, alkaline phosphatase, transaminases, and urinalysis), and another endoscopy with biopsies. The diary cards were checked, the number of antacid tablets taken during the test period was recorded, and any trial medication not consumed was registered. For statistical analysis the $\chi^{2}$ test was used. In the second part of the trial (stage II) patients whose oesophagitis were not healed during stage I received six week open treatment with ranitidine $(150 \mathrm{mg}$ bd), with the same evaluation procedure at the end of the trial period.

\section{Results}

PATIENT CHARACTERISTICS

Two patients were excluded from final analysis; a 56 year old female patient, receiving placebo, stopped the trial medication within 10 days because of persistent complaints and refused further cooperation; a 34 year old male patient receiving placebo, ended the trial after three weeks because he was admitted to the hospital because of severe pain due to a herniated intervertebral disc. The characteristics of the 36 patients who completed stage I of the trial are summarised in Table 1, 19 patients having received ranitidine and 17 placebo. Both groups were comparable for age, sex, duration of disease, severity of symptoms, and the degree of reflux oesophagitis scored endoscopically and histologically.

\section{EXPERIMENTAL RESULTS}

The experimental results are summarised in Table 2 . Stage I There was a significant improvement in symptoms such as heartburn and regurgitation in the ranitidine treated patients. Less retrosternal pain was observed in this ranitidine group, although not significantly so. The daily antacid consumption was slightly lower in the second three week period in the ranitidine group. The difference was not significant. Using endoscopic criteria, 15 of the 19 ranitidine treated patients healed or were definitely improved, whereas four remained unchanged. In the placebo treated group, four patients healed or improved, 10 remained unchanged, and in three the oesophagitis

Table 2 Experimental results (stage I)

\begin{tabular}{|c|c|c|c|c|c|c|c|c|c|}
\hline \multirow[b]{3}{*}{ Symptomatology } & \multicolumn{9}{|c|}{ Treatment group } \\
\hline & \multicolumn{4}{|l|}{ Ranitidine } & \multicolumn{4}{|l|}{ Placebo } & \\
\hline & $\begin{array}{l}\text { Symptom } \\
\text { free }\end{array}$ & Improved & Unchanged & Worse & $\begin{array}{l}\text { Symptom } \\
\text { free }\end{array}$ & Improved & Unchanged & Worse & \\
\hline Heartburn & 6 & 2 & 11 & 0 & 2 & 8 & 7 & 0 & $\mathrm{p}<0.05$ \\
\hline Retrosternal pain & 2 & 6 & 11 & 0 & 0 & 3 & 13 & 1 & NS \\
\hline Regurgitation & 8 & 4 & 5 & 2 & 1 & 5 & 11 & $\mathbf{0}$ & $\mathrm{p}<0.05$ \\
\hline $\begin{array}{l}\text { Antacid consumed/ } \\
3 \text { weeks }(w)^{*}\end{array}$ & $\begin{array}{l}\text { First } 3 w \\
31( \pm 28)\end{array}$ & & $\begin{array}{l}\text { Second } 3 w \\
19( \pm 25)\end{array}$ & & $\begin{array}{l}\text { First } 3 w \\
30( \pm 25)\end{array}$ & & $\begin{array}{l}\text { Second } 3 w \\
25( \pm 22)\end{array}$ & & NS \\
\hline $\begin{array}{l}\text { Endoscopy+histology } \\
\text { evaluation } \\
\text { Endoscopy }\end{array}$ & $\begin{array}{l}\text { Healed } \\
7\end{array}$ & Improved & Unchanged & $\begin{array}{l}\text { Worse } \\
0\end{array}$ & $\begin{array}{l}\text { Healed } \\
2\end{array}$ & Improved & $\begin{array}{l}\text { Unchanged } \\
10\end{array}$ & $\begin{array}{l}\text { Worse } \\
3\end{array}$ & $\mathrm{p}<0.01$ \\
\hline Histology & 1 & 10 & 8 & 0 & 1 & 3 & 11 & 2 & $p<0.05$ \\
\hline
\end{tabular}

* SD is given in parentheses. 
Table 3 Treatment group (stage II)

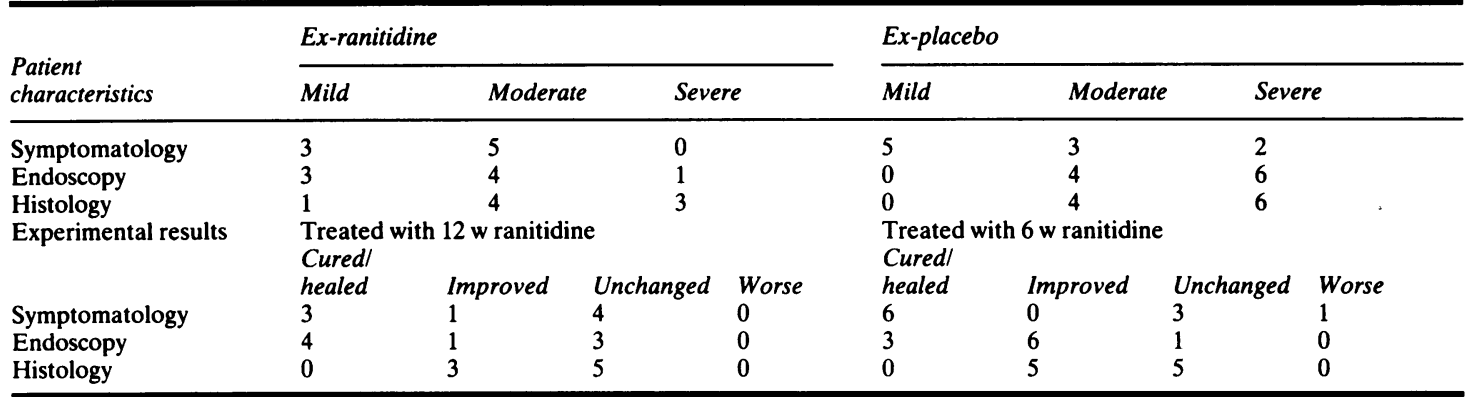

became worse. The statistical difference between the incidence of healing or improvement $v s$ lack of improvement between ranitidine and placebo treated patients was highly significant $(p<0 \cdot 01)$. The overall histological gradings showed improvement or healing in 11 patients during ranitidine treatment, and in four patients during placebo treatment; also a significant difference $(\mathrm{p}<0 \cdot 05)$.

Stage II The characteristics of the 18 patients who received a six week open treatment with ranitidine because they had not healed endoscopically in the stage I period, are summarised in Table 3. As seen, eight patients were treated with ranitidine and 10 with placebo during stage I of the trial. The ex-placebo group had had more serious disease at the start of this stage II of the study regarding endoscopical and histological findings. Another six week treatment with ranitidine in the ex-ranitidine group resulted in improved symptomatology, endoscopical, and histological findings in approximately half of the patients, while this improvement was more pronounced in the ex-placebo group, now receiving ranitidine for six weeks, as can be also seen in Table 3.

\section{Discussion}

The double blind prospective study (stage I) showed that ranitidine is superior to placebo in the acute treatment of patients with endoscopically moderate or severe reflux oesophagitis. The results of this six week study 'compare well with the results of double blind trials with cimetidine in patients with endoscopically and histologically established reflux oesophagitis, reporting endoscopic improvement in $67 \%$ of the patients treated for eight to 12 weeks with cimetidine $1.6 \mathrm{~g} /$ day. ${ }^{5612}$ To achieve better results, the acute treatment may have to be continued for 12 weeks as shown in the stage II period of the trial. Until now, the problem of preventing the recurrence of gastrooesophageal reflux disease has been unresolved. Possibly a lower dose, such as an evening dose, or intermittent drug therapy together with antireflux measurements will prove to be sufficient. Further long-term maintenance therapy studies in a substantial number of patients are needed to know how to reduce the relapse rate in this complex disease. Like cimetidine, ranitidine proved to be a safe and clinically well tolerated drug and appears to be another useful drug in the treatment of reflux oesophagitis.

\section{References}

1 Richardson CT. Effect of $\mathbf{H}_{2}$-receptor antagonists on gastric acid secretion and serum gastrin concentration. A review. Gastroenterology 1978; 74: 366-70.

2 Longstreth GF, Go VLW, Malagelada J-R. Postprandial gastric, pancreatic, and biliary response to histamine $\mathbf{H}_{2}$-receptor antagonists in active duodenal ulcer. Gastroenterology 1977; 72: 9-13.

3 Aadland E, Berstad A. Effect of cimetidine on pentagastrin-stimulated gastric acid and pepsin secretion before and after 6 weeks of cimetidine treatment. Scand J Gastroenterol 1978; 13: 193- .

4 Konturek SJ, Obtulewicz W, Kwiecien N, Sito E, Mikos E, Oleksy J. Comparison of ranitidine and cimetidine in the inhibition of histamine, sham-feeding, and meal-induced gastric secretion in duodenal ulcer patients. Gut 1980; 21 : 181-6.

5 Lepsien G, Sonnenberg A, Berges W et al. Die behandlung der reflux ösophagitis mit cimetidin. Dtsch Med Wochenschr 1979; 25: 901-6.

6 Wesdorp E, Bartelsman J, Pape K, Dekker W, Tytgat GN. Oral cimetidine in reflux esophagitis: a double blind controlled trial. Gastroenterology 1978; 74: 821-4.

7 Behar J, Brand DL, Brown FC, Castell DO, Cohen S, Crossley RJ, Pope CE, Winas CS. Cimetidine in the treatment of symptomatic gastroesophageal reflux. A double blind controlled trial. Gastroenterology 1978; 74: 441-7. 
8 Brown P. Cimetidine in the treatment of reflux oesophagitis. Med J Aust 1979; 2: 96-7.

9 Damman HG, Kather H, Augustin HJ, Simon B. Untersuchung über die wirkungsdauer von ranitidine. Dtsch Med Wochenschr 1980; 105: 603-5.

10 Bertaccini G, Molina E, Bobbio P, Foggi E. Ranitidine increases lower oesophageal sphincter pressure in man. Ital J Gastroenterol 1981; 13: 147-50.
11 Denis Ph, Galmiche, Ducrotte $\mathrm{Ph}$, Colin R, Pasquis $\mathrm{P}$, Lefrancois $R$. Effect of ranitidine on resting pressure and pentagastrin response of human lower esophagel sphincter. Dig Dis Sci 1981; 26: 999-1002.

12 Tytgat GN. Assessment on the efficacy of cimetidine and other drugs in oesophageal reflux. In: Baron $\mathrm{JH}$, ed. Cimetidine in the 80's. Edinburgh: Churchill Livingstone, 1981: 153-66. 